\title{
Multiplication and Movement of a Citrus Strain of Xylella fastidiosa Within Sweet Orange
}

\author{
R. P. P. Almeida and E. F. Pereira, Departamento de Entomologia, Fitopatologia e Zoologia Agrícola, \\ ESALQ/Universidade de São Paulo, Piracicaba, SP 13418-900, Brazil; A. H. Purcell, Department of Environ- \\ mental Science, Policy and Management, University of California, Berkeley 94720-3112; and J. R. S. Lopes, \\ Departamento de Entomologia, Fitopatologia e Zoologia Agrícola, Universidade de São Paulo, Brazil
}

\begin{abstract}
Almeida, R. P. P., Pereira, E. F., Purcell, A. H., and Lopes, J. R. S. 2001. Multiplication and movement of a citrus strain of Xylella fastidiosa within sweet orange. Plant Dis. 85:382-386.

Populations of cultivable cells of a citrus variegated chlorosis (CVC) disease strain of Xylella fastidiosa in stems and leaf veins of sweet orange (Citrus sinensis (L.) Osbeck) seedlings were estimated by dilution plating at $1,2,4,8$, and 16 weeks after needle inoculation. Cell populations ranged from $\log 4$ to $\log 5 \mathrm{CFU} / \mathrm{g}$ of tissue after 1 week and increased to $\log 5$ to $\log 7$ $\mathrm{CFU} / \mathrm{g}$ (median $\log 6$ ) after 8 to 16 weeks. Recovery of greater than $\log 5 \mathrm{CFU} / \mathrm{g}$ from stem nodes distal to the inoculation site indicated systemic movement of the bacteria. Foliar symptoms in inoculated seedlings first appeared after 8 weeks. Population estimates from leaf veins of CVC-affected trees in citrus groves were in the same range but slightly lower (average log $5.8 \mathrm{CFU} / \mathrm{g}$ ). X. fastidiosa was isolated from citrus more efficiently in periwinkle wilt-GelRite (PWG) and periwinkle wilt (PW) media than in charcoal-yeast extract with ACES buffer (BCYE) medium The relatively lower populations of cultivable cells of $X$. fastidiosa in citrus with CVC symptoms, compared with those reported in grapevines with Pierce's disease, suggest that most cells of $X$. fastidiosa within symptomatic citrus may be dead, explaining in part the low rates of vector transmission from citrus to citrus.
\end{abstract}

Additional keywords: xylem-inhabiting bacteria

Citrus variegated chlorosis (CVC), caused by the xylem-limited bacterium Xylella fastidiosa, has arisen from obscurity to become a major threat to the Brazilian citrus industry in less than 10 years. Since $X$. fastidiosa was first shown to cause CVC $(3,20)$, serological (5) and molecular methods $(1,21,25)$ have been developed to detect the bacterium in citrus. The pathogen is naturally transmitted to citrus by sharpshooter (Cicadellinae) leafhoppers (29). Transmission by natural root grafts and by top grafting with infected budsticks also were reported (10). Epidemiological studies suggest that most spread of CVC is from tree to tree within the citrus groves (19). Therefore, management of CVC is mainly based on planting healthy nursery trees, vector control, and removal of inoculum by roguing of symptomatic

Corresponding author: J. R. S. Lopes

E-mail: jrslopes@ carpa.ciagri.usp.br

The research was supported by FAPESP (Fundação de Amparo à Pesquisa do Estado de São Paulo) (Proc. No. 99/04342-4 and 98/136949) and FUNDECITRUS (Fundo de Defesa da Citricultura); R. P. P. Almeida received a scholarship from FAPESP (Proc. No. 98/02838-0).

Accepted for publication 1 December 2000.

Publication no. D-2001-0219-01R

(C) 2001 The American Phytopathological Society young plants ( $<2$ years old) and pruning of branches with early foliar symptoms in older trees $(8,30)$. The population behavior of $X$. fastidiosa within citrus is crucial to its pathology and control, but bacterial colonization of citrus has not been studied quantitatively and some characteristics of infection, movement of $X$. fastidiosa within citrus, and disease development remain unknown. He et al. (10) used polymerase chain reaction (PCR) and enzyme-linked immunosorbent assay (ELISA) to detect movement of $X$. fastidiosa from scion graft to rootstock but did not quantify populations of the pathogen.

A limiting factor to studies concerning $X$. fastidiosa is the slow growth of the pathogen on solid medium, leading to frequent contamination of culture attempts. This has hindered attempts to quantify populations of $X$. fastidiosa. Hopkins (14) developed a protocol to estimate population of viable $X$. fastidiosa cells from grapevines with Pierce's disease (PD) based on counting CFU of this bacterium on solid media by dilution plating. A modification of this technique (11) was used to study PD strains of $X$. fastidiosa in alternative hosts, with the bacterium reaching high populations $(\log 8 \mathrm{CFU} / \mathrm{g}$ of plant tissue) in grapevine, 100-fold lower populations in an asymptomatic host, Himalayan blackberry, and still lower, nonsys- temic populations in water grass and mugwort. Populations of $X$. fastidiosa estimated by dilution plating were also correlated with vector transmission rates; bacterial populations lower than $\log 6$ to $\log 7 \mathrm{CFU} / \mathrm{g}$ determined by culture in grapevine resulted in reduced transmission efficiency (13).

The objective of our study was to follow the fate of a CVC strain of X. fastidiosa in citrus seedlings under greenhouse conditions and to estimate population levels of $X$. fastidiosa in symptomatic leaves of infected citrus trees in commercial orchards. We used culturing to quantify $X$. fastidiosa in leaves collected from the field and its growth and movement within citrus seedlings, following mechanical inoculation in the stem and leaf petioles with variable concentrations of live cells. We also tested different media for $X$. fastidiosa growth and evaluated citrus tissue homogenates for inhibition of bacterial growth in vitro.

\section{MATERIALS AND METHODS}

Field samples. Symptomatic leaves were collected from 4-year-old commercial sweet orange (Citrus sinensis (L.) Osbeck) orchards located near Neves Paulista, Gavião Peixoto, and St. Rita do Passa Quatro, which are representative of the northern, central, and southern citrus regions, respectively, of São Paulo State, Brazil. From February to June 1999, a period when CVC symptoms are most obvious in the field, leaves were picked monthly from 20 infected trees of each orchard, put in plastic bags, and taken to the laboratory. Samples were processed immediately or stored in a refrigerator for a maximum period of 2 days. Only mature leaves with yellow spots on the upper surface and a brown pustule directly opposite on the underside (diagnostic symptom) were considered symptomatic (31). A total of 143 leaves from the three areas were processed during the evaluation period. Leaves from healthy sweet orange seedlings kept on insect-free greenhouse plants were sampled and tested as negative controls concurrently with field-collected materials. Data from the different areas were analyzed by analysis of variance (ANOVA).

Culture and quantification of $X$. fastidiosa. Methods for isolation and quantification of $X$. fastidiosa were adapted from 
Hill and Purcell (11). Approximately 0.05 to $0.1 \mathrm{~g}$ of citrus tissue sample (stems, petioles, and midveins) were weighed, surface sterilized, chopped into small pieces, and transferred to disposable glass test tubes (16 $\mathrm{mm}$ in diameter) containing $2 \mathrm{ml}$ of sterile phosphate saline buffer (PBS). Samples were homogenized at 25,000 rpm in a tissue homogenizer (model Turrax; Marconi S.A., Piracicaba, SP, Brazil). In our first trial of this method, 20 symptomatic leaves were taken from each field site and processed as above. The contamination rates observed were 90, 70, and $70 \%$ for St. Rita do Passa Quatro, Neves Paulista, and Gavião Peixoto, respectively. To overcome the contamination problem, we used a 10 -fold dilution of the homogenized suspension by transferring an aliquot of the original homogenate to another test tube with $2 \mathrm{ml}$ of PBS and plating the sample twice. For the multiplication and movement experiment, two $20-\mu \mathrm{l}$ aliquots of the undiluted suspension and a 100 -fold dilution from each sample were plated onto periwinkle wilt-GelRite (PWG) solid medium (11). Plates were incubated at $28^{\circ} \mathrm{C}$ and the average number of CFU from the two platings counted 14 days later. The identity of the $X$. fastidiosa colonies was confirmed based on colony morphology and growth pattern. In addition, samples of single colonies were tested by PCR, using specific primers $(1,21)$, and by ELISA with polyclonal antiserum against $X$. fastidiosa of citrus (SANOFI; Diagnostics Pasteur S.A., France). All colony samples visually identified as $X$. fastidiosa were positive in these tests.

Media comparison. Three media for isolating $X$. fastidiosa were compared: PWG, periwinkle wilt (PW) (4), and charcoal-yeast extract with ACES buffer (BCYE) (32). Plants infected with $X$. fastidiosa were obtained from a vector transmission experiment done in our lab (18), whose original source plant was obtained in 1997 by grafting infected citrus buds from the Bebedouro citrus region, at Northern São Paulo State. Ten symptomatic leaves from one of the source plants were processed as described above, and 10-fold dilutions of the obtained suspensions were plated three times on each medium. Colony appearance was observed daily under a dissecting scope $(\times 25)$. Colony diameter (10 randomly selected colonies per plate) and number of CFU were evaluated 14 and 21 days after plating. This test was repeated three times, each time using a different source plant. Isolating efficiency was measured in relation to PWG medium; colony diameter data were analyzed by ANOVA and means compared by Tukey test $(\alpha=0.05)$.

Bacterial growth inhibitors in citrus. To investigate the possible inhibition of $X$. fastidiosa growth in vitro by homogenized citrus tissue, we prepared tubes with $2 \mathrm{ml}$ of a suspension $(\log 8 \mathrm{CFU} / \mathrm{ml})$ of
CCT6570 (an isolate from one of the citrus source plants, which is deposited at Fundação "André Tosello" culture collection, Campinas, SP, Brazil, access \# CCT6570) in PBS. Four treatments were made with this cell suspension: (i) addition of $0.05 \mathrm{~g}$ of healthy citrus stem previously surface sterilized; (ii) addition of $0.05 \mathrm{~g}$ of sterilized healthy citrus petiole and leaf midvein; (iii) and (iv) were PBS. Treatments i, ii, and iii were homogenized at 25,000 rpm as described, whereas iv was a nonhomogenized control. Suspensions were diluted $10^{-4}$ and $10^{-6}$ times after processing and two $20-\mu \mathrm{l}$ aliquots of each dilution were plated on solid PWG medium; CFU were counted 14 days later. Each treatment was replicated six times and means of each sample were pooled. The experiment was repeated once, but treatment iii was lost in the second repetition. Data were evaluated by ANOVA.

Multiplication and movement experiments. Three experiments (A, B, and C) evaluated the multiplication and movement of $X$. fastidiosa within sweet orange seedlings (Citrus sinensis, cv. Caipira) that were 15 to $20 \mathrm{~cm}$ in height. The seedlings were grown in 1-liter plastic bags with soil mixture (one-half soil, one-quarter sand, one-quarter cow dung and phosphate fertilizer) and kept before and after inoculation inside a closed glasshouse (20 to $32^{\circ} \mathrm{C}$ ) which was distant from citrus groves with CVC. Low passage ( 2 to 5) cultures of CCT6570 were used for mechanical inoculations of sweet orange seedlings. Needle inoculation was done by probing five times with a number 0 insect pin through a $2-\mu \mathrm{l}$ drop of bacterial suspension of strain CCT6570 in PBS into the stem or petiole of the seedlings. Two months after the inoculation of $X$. fastidiosa, the test plants were transferred to larger bags (10liter) and fertilized with nitrogen. A total of 12 to 20 test plants were destructively sampled for dilution plating at 1, 2, 4, 8, and 16 weeks after inoculation. Symptoms of CVC were recorded and mapped weekly.

The first inoculations (experiment A) were made in early summer, in December 1998. The remaining inoculations (experiments $\mathrm{B}$ and $\mathrm{C}$ ) were made in late January 1999. In experiment A, a $\log 6 \mathrm{CFU} / \mathrm{ml}$ suspension of CCT6570 was used to in- oculate the young stems of the test plants. In each evaluation period, three samples were taken from each plant at the following locations: (i) inoculation point (area of stem in which inoculation puncture was done), (ii) $1-\mathrm{cm}$ section of stem immediately distal to that area, and (iii) first leaf (petiole and half midvein) distal to the inoculation point. In the last evaluation (16 weeks), an additional leaf 25 to $30 \mathrm{~cm}$ above the inoculation point was sampled. In a second stem-inoculating experiment (B), the inoculum was a $\log 8 \mathrm{CFU} / \mathrm{ml}$ suspension, and two additional sampling points in the stem were used: one located 4 $\mathrm{cm}$ below the inoculation point and another $4 \mathrm{~cm}$ above that area. The nearest leaf located at least $15 \mathrm{~cm}$ above the inoculation point was sampled after 16 weeks. In the third experiment $(\mathrm{C})$, leaf petioles were inoculated with a $\log 8 \mathrm{CFU} / \mathrm{ml}$ suspension, and three points were sampled per test plant: (i) inoculated leaf (petiole and midvein), (ii) $1-\mathrm{cm}$ section of stem distal to the inoculated petiole, and (iii) $1-\mathrm{cm}$ section of stem basal to that area. The nearest leaf located at least $15 \mathrm{~cm}$ distal to the inoculated petiole was also sampled after 16 weeks. Groups of 25,10 , and 5 negative control plants were inoculated only with PBS in experiments $\mathrm{A}, \mathrm{B}$, and $\mathrm{C}$, respectively, and 5 (A), 2 (B), and 1 (C) control plants were sampled during each evaluation period. Symptomatic leaves were sampled 16 weeks after inoculation in experiment A, as previously described, to determine the population of $X$. fastidiosa in symptomatic tissue. The median of positive samples was used to represent bacterial populations in the evaluations.

\section{RESULTS}

Isolation of $X$. fastidiosa from field samples. $X$. fastidiosa was cultured without contaminants from citrus from over $70 \%$ of the symptomatic leaves sampled (Table 1). All single colonies tested were positive for $X$. fastidiosa by light microscopy, ELISA, and PCR. No colonies were recovered from the healthy leaves (negative controls). The contamination rates were considerably lower than the values obtained in preliminary trials (70 to $90 \%$ ), in which undiluted suspensions were plated. These results show that a 10-fold dilution is satisfactory for overcoming

Table 1. Recovery rates and populations of Xylella fastidiosa from symptomatic citrus leaves collected from São Paulo State

\begin{tabular}{lccccc}
\hline & & \multicolumn{3}{c}{ Percentage of leaf samples tested } & \\
\cline { 3 - 5 } Area & No. sampled $^{\mathbf{y}}$ & Positive & Negative & Contaminated & Mean $^{\mathbf{z}}$ \\
\hline St. Rita do Passa Quatro & 45 & 71.1 & 11.1 & 17.8 & $5.56 \pm 0.14 \mathrm{a}$ \\
Neves Paulista & 51 & 80.4 & 7.8 & 11.8 & $5.91 \pm 0.10 \mathrm{a}$ \\
Gavião Peixoto & 47 & 72.3 & 19.1 & 8.5 & $5.77 \pm 0.11 \mathrm{a}$ \\
All areas combined & 143 & 74.8 & 12.6 & 12.6 & $5.76 \pm 0.07$ \\
\hline
\end{tabular}

y Number of leaves sampled.

${ }^{z}$ Mean population (log CFU/g; means \pm standard error of means) followed by the same lowercase letter are not significantly different $(P \geq 0.1)$ by analysis of variance. Population data includes only positive samples. 
contamination problems with field-collected samples, without too much reduction in the test sensitivity. The contaminants usually appeared 2 to 3 days after plating the suspensions.

No significant differences in $X$. fastidiosa populations were observed among the localities surveyed during the sampling period (February to June 1999) of this study (Table 1). Overall average population was $\log 5.8$ $\mathrm{CFU} / \mathrm{g}$ of tissue. $X$. fastidiosa was not cultured from 7.8 to $19.1 \%$ of the symptomatic leaves assayed, suggesting that populations of viable bacteria in those leaves could be lower than $\log 3 \mathrm{CFU} / \mathrm{g}$, which is the theoretical threshold for this dilution plating method, and still exhibit symptoms.

Media comparison. $X$. fastidiosa was successfully cultured from infected citrus in all three media tested. Cultures in PW and PWG had shorter incubation periods, higher rates of colony recovery, and larger colonies than in BCYE for isolate A (Table 2). PWG also increased the colony size of isolate $\mathrm{A}$, but not of isolates $\mathrm{B}$ and $\mathrm{C}$. Mean colony size was quite variable depending on the isolate, ranging from 0.46 to $1.40 \mathrm{~mm}$ in diameter (Table 2).

Bacterial growth inhibitors. The homogenization of $X$. fastidiosa suspension with citrus tissue did not inhibit bacterial growth on solid medium. In fact, bacterial suspensions homogenized with either stems or leaves had 10-fold higher populations of surviving $X$. fastidiosa $(\log 7.42 \pm$ 0.02 and $7.28 \pm 0.02 \mathrm{CFU} / \mathrm{ml}$, respectively, $P<0.01$ by ANOVA) after plating than did the nonhomogenized and homogenized

Table 2. Comparison of artificial media for culturing Xylella fastidiosa from citrus leaves with citrus variegated chlorosis disease symptoms

\begin{tabular}{|c|c|c|c|c|}
\hline \multirow[b]{2}{*}{ Experiment, medium $^{x}$} & \multirow[b]{2}{*}{ Inc. per. $(\text { days })^{y}$} & \multirow[b]{2}{*}{ Isolation $(\%)^{\mathbf{z}}$} & \multicolumn{2}{|c|}{ Colony diameter $(\mathrm{mm})^{\mathrm{w}}$} \\
\hline & & & 14 days & 21 days \\
\hline \multicolumn{5}{|l|}{ A } \\
\hline PWG & $7-8$ & 100.0 & $1.17 \pm 0.04 \mathrm{a}$ & $1.39 \pm 0.04 \mathrm{a}$ \\
\hline PW & $7-8$ & 82.2 & $0.78 \pm 0.02 b$ & $1.09 \pm 0.04 b$ \\
\hline BCYE & $14-15$ & 32.0 & $\ldots$ & $0.43 \pm 0.02 \mathrm{c}$ \\
\hline \multicolumn{5}{|l|}{ B } \\
\hline PWG & $7-8$ & 100.0 & $\ldots$ & $1.28 \pm 0.06 \mathrm{a}$ \\
\hline PW & $7-8$ & 88.4 & $\ldots$ & $1.40 \pm 0.07 \mathrm{a}$ \\
\hline \multicolumn{5}{|r|}{ 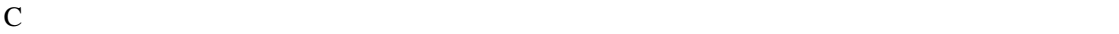 } \\
\hline PWG & $7-8$ & 100.0 & $\ldots$ & $0.49 \pm 0.03 a$ \\
\hline PW & $7-8$ & 87.9 & $\ldots$ & $0.46 \pm 0.03 a$ \\
\hline
\end{tabular}

${ }^{\mathrm{w}}$ Average colony diameter $(n=10)$. Means ( \pm standard error of mean) followed by the same lowercase letter each are not significantly different by Tukey $(\alpha=0.05) ; \ldots=$ not done.

${ }^{\mathrm{x}}$ Each experiment consisted of isolation from a different source plant (10 symptomatic leaves per plant). $\mathrm{PWG}=$ periwinkle wilt-GelRite, $\mathrm{PW}=$ periwinkle wilt, $\mathrm{BCYE}=$ charcoal-yeast extract with ACES buffer.

${ }^{\mathrm{y}}$ Incubation period.

${ }^{\mathrm{z}}$ Isolation efficiency; percentage of recovered colonies relative to PWG medium. $(\log 6.89 \pm 0.06$ and $\log 6.54 \pm 0.06$ $\mathrm{CFU} / \mathrm{ml}$, respectively) suspensions in PBS alone $(P<0.01$ by ANOVA). About 5\% more $\mathrm{CFU} / \mathrm{ml}$ were observed for nonhomogenized suspensions compared with homogenized suspensions $(P<0.01$ by ANOVA), which may represent bacterial mortality caused by homogenization or measurement errors introduced by residual water used to rinse the homogenizer blades. The repetition of the experiment showed a similar trend.

Multiplication and movement of $X$. fastidiosa within citrus seedlings. Mechanical inoculation of $X$. fastidiosa by using an insect pin was efficient. The lowest inoculum concentration tested $(\log 6$ $\mathrm{CFU} / \mathrm{ml}$, experiment $\mathrm{A}$ ), resulted in a $62.4 \%$ average infection rate. Using a concentration of $\log 8 \mathrm{CFU} / \mathrm{ml}$ increased the average rate of detectable infection to $83.2 \%$ in experiment B and to $72.3 \%$ in C. $X$. fastidiosa colonies were not recovered from any of the negative control plants. Contaminants precluded detection of $X$. fastidiosa in some undiluted samples; only the 100-fold dilution was available for these samples, thus reducing the test sensitivity and probably underestimating the rate of positive samples from plants that had lower populations of $X$. fastidiosa. Contamination rates for experiments A, B, and $\mathrm{C}$, averaged for all dates, were 12.5, 18.0 , and $47.9 \%$, respectively. We suspect that most contaminants might be bacteria that colonized minute internalized wounds not disinfected by surface sterilization.

In the first two experiments (A and B), $X$. fastidiosa was recovered from the stem above the inoculation point 1 week after inoculation (Table 3). The rate of culturing $X$. fastidiosa increased over time at the first

Table 3. Isolation of Xylella fastidiosa from the stem and leaf of citrus seedlings at various distances from the inoculation point after mechanical inoculation in three experiments

\begin{tabular}{|c|c|c|c|c|c|c|c|c|}
\hline \multirow[b]{2}{*}{ Experiment, week $^{\mathbf{y}}$} & \multirow[b]{2}{*}{$n^{\mathbf{z}}$} & \multicolumn{7}{|c|}{$\%$ of positive samples (minimum-maximum log CFU/g of tissue) ${ }^{x}$} \\
\hline & & Total & Inoc. & Distal & First & Below & Above & Basal \\
\hline \multicolumn{9}{|l|}{ A } \\
\hline 1 & 15 & 66.7 & $13.3(5-5)$ & $66.7(3-5)$ & 0.0 & $\ldots$ & $\ldots$ & $\ldots$ \\
\hline 2 & 20 & 50.0 & $10.0(3-3)$ & $40.0(3-5)$ & $25.0(4-7)$ & $\ldots$ & $\ldots$ & $\ldots$ \\
\hline 4 & 19 & 68.4 & $31.6(3-6)$ & $63.2(3-6)$ & $42.1(4-7)$ & $\ldots$ & $\ldots$ & $\ldots$ \\
\hline 8 & 19 & 73.7 & $26.3(3-6)$ & $63.2(2-6)$ & $47.4(5-7)$ & $\ldots$ & $\ldots$ & $\ldots$ \\
\hline 16 & 15 & 53.3 & $13.3(4-4)$ & $6.7(5)$ & $53.3(5-6)$ & $\ldots$ & $\ldots$ & $\ldots$ \\
\hline \multicolumn{9}{|l|}{ B } \\
\hline 1 & 14 & 78.6 & $28.6(3-5)$ & $71.4(3-6)$ & $14.3(3-5)$ & $35.7(3-5)$ & $21.4(3-6)$ & $\ldots$ \\
\hline 2 & 14 & 92.9 & $50.0(4-6)$ & $78.6(3-5)$ & $64.3(5-6)$ & $50.0(3-6)$ & 0.0 & $\ldots$ \\
\hline 4 & 14 & 100.0 & $35.7(3-5)$ & $85.7(4-6)$ & $78.6(3-7)$ & $35.7(3-6)$ & $14.3(5-6)$ & $\ldots$ \\
\hline 8 & 14 & 57.1 & $35.7(4-6)$ & $57.1(3-6)$ & $57.1(4-6)$ & $42.9(5-6)$ & $28.6(5-6)$ & $\ldots$ \\
\hline 16 & 16 & 87.5 & $37.5(3-6)$ & $68.8(3-5)$ & $68.8(5-6)$ & $43.8(3-5)$ & $31.3(3-5)$ & $\ldots$ \\
\hline \multicolumn{9}{|c|}{ 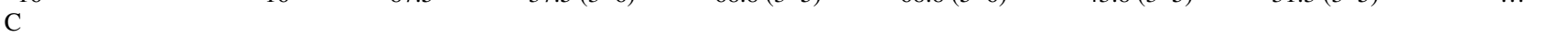 } \\
\hline 1 & 12 & 66.7 & $58.3(3-4)$ & 0.0 & $\ldots$ & $\ldots$ & $\ldots$ & $16.7(2-4)$ \\
\hline 2 & 11 & 45.5 & $36.4(3-5)$ & $9.1(4)$ & $\ldots$ & $\ldots$ & $\ldots$ & $9.1(4)$ \\
\hline 4 & 12 & 83.3 & $83.3(3-7)$ & 0.0 & $\ldots$ & $\ldots$ & $\ldots$ & $33.3(4-5)$ \\
\hline 8 & 12 & 75.0 & $75.0(4-6)$ & $16.7(5-5)$ & $\ldots$ & $\ldots$ & $\ldots$ & $50.0(4-6)$ \\
\hline 16 & 11 & 90.9 & $90.9(4-6)$ & $72.7(4-6)$ & $\ldots$ & $\ldots$ & $\ldots$ & $72.7(5-6)$ \\
\hline
\end{tabular}

$\mathrm{x}$ Total $=$ percentage of test plants from which bacterium was cultured; Inoc. $=$ inoculated area; Distal $=$ stem distal to inoculation; First $=$ first distal leaf; Below and Above $=$ stem $4 \mathrm{~cm}$ below and above inoculation, respectively; Basal $=$ stem basal to inoculation; and $\ldots=$ not done.

y $\mathrm{A}=$ Stem inoculated, $\log 6 \mathrm{CFU} / \mathrm{ml}$ (concentration of bacterial suspension used in needle inoculation, $2 \mu \mathrm{l}$ of suspension for each test plant); $\mathrm{B}=$ stem inoculated, $\log 8 \mathrm{CFU} / \mathrm{ml}$; and $\mathrm{C}=$ leaf inoculated, $\log 8 \mathrm{CFU} / \mathrm{ml}$; evaluation period = week number after inoculation.

z Number of tested plants. 
distal leaf position (experiments A and B) and stem above and below the inoculation point (experiment B) (Table 3), demonstrating rapid initial colonization of xylem vessels and movement of the pathogen within the host. As soon as 1 week after inoculation, $X$. fastidiosa was detected 4 $\mathrm{cm}$ below and above the inoculation point in experiment $\mathrm{B}$. The reduced percentage of positives from stem samples taken 16 weeks after inoculation in experiment A may have been caused by xylem tissues constituting a smaller proportion of the stem, due to xylem secondary growth and sample weight limitations.

Systemic movement was shown by culturing of $X$. fastidiosa from leaves, following inoculations of the stem, and from parts of the stem $4 \mathrm{~cm}$ above the inoculation point 1 to 2 weeks after leaves were inoculated (Table 3). In addition, X. fastidiosa was recovered from $33 \%$ of leaves sampled $30 \mathrm{~cm}$ above the inoculation points after 16 weeks in experiment $\mathrm{A}$, and the bacterial population in those samples ranged from $\log 4$ to $\log 6 \mathrm{CFU} / \mathrm{g}$ of tissue. Similar results were observed in experiment B in leaves sampled $15 \mathrm{~cm}$ above the inoculation point: $31 \%$ bacterial infection and $\log 2$ to $\log 6 \mathrm{CFU} / \mathrm{g}$. However, in experiment $\mathrm{C}$, no bacteria were recovered after 16 weeks from leaves located $15 \mathrm{~cm}$ above the inoculation point.

Medians of population estimates of $X$. fastidiosa in the seedlings ranged from log 5 to $\log 6 \mathrm{CFU} / \mathrm{g}$ at 4 weeks after inoculation and remained fairly stable thereafter, except in experiment $\mathrm{C}$, where a maximum population of $\log 7 \mathrm{CFU} / \mathrm{g}$ was observed in the inoculated leaf at 16 weeks (Fig. 1). In the stem-inoculating experiments (A and B), the first distal leaf and stem $4 \mathrm{~cm}$ above the inoculation point showed the highest bacterial populations (around log 6.5 CFU/g) at 8 weeks after inoculation.

In all experiments, CVC foliar symptoms first appeared 2 months after inoculation. Usually, leaves immediately above the area of inoculation were the first ones to show interveinal chlorosis, but symptomatic leaves above and below that area were also observed within 16 weeks. The most distant symptomatic leaves were the seventh distal to and the fourth basal to the inoculation point. After 16 weeks, the number of symptomatic leaves per plant ranged from one to seven, with an average of two per plant. All symptomatic leaves evaluated in experiment A were positive by culturing, with a population range of $\log 5$ to $\log 7 \mathrm{CFU} / \mathrm{g}$.

\section{DISCUSSION}

The populations of cultivable cells of $X$. fastidiosa in midveins of sweet orange leaves with CVC symptoms were $10^{2}$ to $10^{3}$ times lower than in grapevines with PD, but were similar to those detected in some symptomless but systemic hosts of PD strains of $X$. fastidiosa such as black- berry (12), periwinkle, French broom, elderberry, and others (28). Microscopic examinations of veins in CVC-symptomatic leaves revealed xylem cells packed with $X$. fastidiosa $(2,23)$, as has also been observed in grape with PD (16). Chronic water blockage by bacterial occlusions of the xylem system appears to cause symptoms of PD (6).

One explanation for this discrepancy between expected and observed populations of $X$. fastidiosa in citrus might be that most cells observed in histological sections of leaf vascular tissue are dead. A second possibility is that $X$. fastidiosa colonizes a smaller proportion of the xylem system of citrus than of grapes. Neither hypothesis excludes the other, and both are consistent with the long incubation period observed for $\mathrm{CVC}$ and the low efficiency of vector transmission from citrus to citrus for CVC strains of $X$. fastidiosa (18).

PWG and PW gave similar results in media comparison tests, as expected due to their compositional similarity, but BCYE medium was less efficient for primary isolation of $X$. fastidiosa from citrus. Although it was less efficient, the dark color of BCYE medium made colonies easier to observe. The slight but consistently better growth of $X$. fastidiosa on PWG medium suggests that bacteriological agar contained growth inhibitors. Our observations of enhanced bacterial growth in vitro in the presence of homogenized citrus tissue were unexpected, but corroborate previous observations by Hartung et al. (9) that citrus homogenates stimulated growth of $X$. fastidiosa. We do not know why citrus homogenates enhance bacterial growth, but the identification of the compounds involved could lead to improved media for CVC strains.

$X$. fastidiosa spread rapidly in citrus seedlings and reached populations of up to $\log 7 \mathrm{CFU} / \mathrm{g}$ of tissue by 4 weeks after infection. However, the titer of live cells in sampled tissues did not increase substantially between 4 and 16 weeks, during the warmest months of January and February or during cooler periods in the fall, or even after symptoms started to be observed 2 months after inoculation. This movement of the pathogen in early stages of infection, with low populations of bacteria, demonstrates that high populations ( $>\log 7 \mathrm{CFU} / \mathrm{g}$ of tissue) of live cells are not required for systemic movement, as previous work suggested for different hosts of X. fastidiosa in California (12). Bacterial detection in the stem $4 \mathrm{~cm}$ below the inoculation point just 1 week after inoculation, as well as the observation of symptomatic leaves below the inoculated area, show downward movement of $X$. fastidiosa in citrus. These observations are in agreement with a previous report of translocation of $X$. fastidiosa to the root system of citrus rootstocks after top grafting with budsticks from CVC-affected trees (10).
The populations of $X$. fastidiosa in our pinprick inoculation experiments in the greenhouse were similar to those observed in symptomatic leaves collected from the field, suggesting that the experimental methods did not produce unusually low bacterial populations. The experiments were performed during months with high temperatures, when bacterial growth was expected to have been maximal. The rapid colonization of $X$. fastidiosa and expression of CVC diagnostic symptoms in young sweet orange seedlings indicates that the needle inoculation technique can be very useful in a variety of physiological or pathogenicity studies in which mechanical inoculation of cultured bacteria and known concentrations of inoculum are required.

Our results confirm that $\mathrm{CVC}$ strains of $X$. fastidiosa are propagative, systemic, and pathogenic in citrus, but the numbers of viable CFU per gram of citrus tissue compared to the much higher numbers of $\mathrm{CFU}$

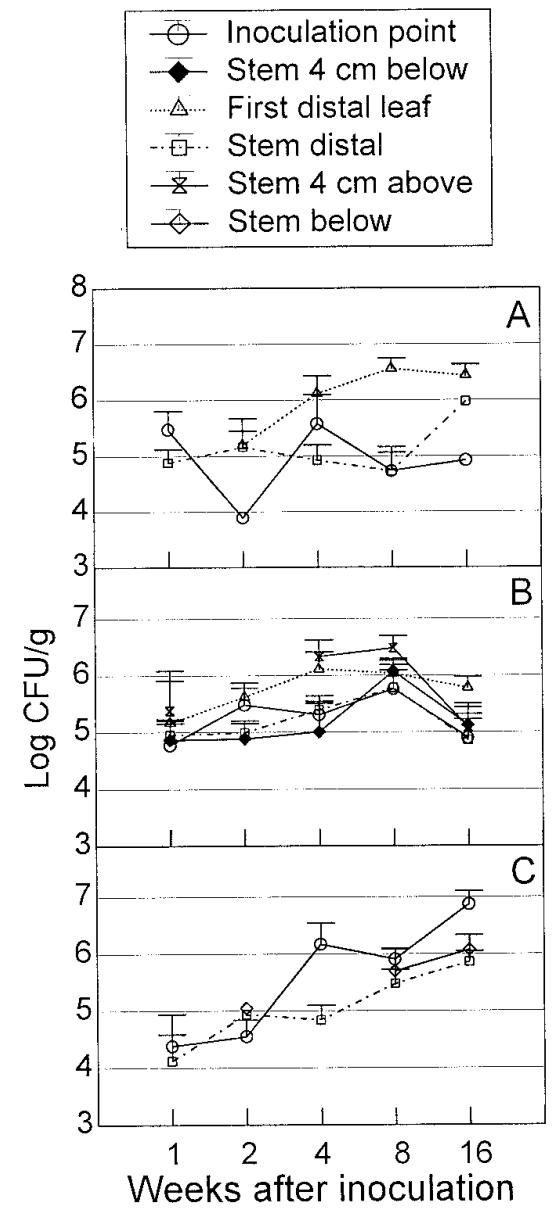

Fig. 1. Median of population estimates of $X y$ lella fastidiosa in the stem and leaf of citrus seedlings at various weeks after needle inoculation of cell suspensions with $\log 6,8$, and 8 $\mathrm{CFU} / \mathrm{ml}$ in experiments $\mathrm{A}, \mathrm{B}$, and $\mathrm{C}$, respectively. Inoculations were done $\mathbf{A}$ and $\mathbf{B}$, in the stem or $\mathbf{C}$, in the leaf petiole. Error bars represent standard error of the mean. 
recovered from grapevines with $\mathrm{PD}$ is a major difference between the two diseases. Mizubuti et al. (23) observed that only 5 to $10 \%$ of sweet orange xylem vessels in cross sections of CVC-symptomatic leaves were colonized by $X$. fastidiosa; infected vessel lumens were totally obstructed or showed cell walls covered by bacteria. These rates of vessel colonization are lower than those observed for almond leaf scorch, 10 to $15 \%$ (22); and up to $18 \%$ in PD (17). However, vessel blockage occurs in different cross sections through the length of a petiole, thereby increasing the final number of obstructed cells viewed in any single cross section examined by microscopy (15).

Dissemination of CVC within orchards can be rapid (19), suggesting efficient transmission of the pathogen, but the reported vector transmission efficiency by five vector species is low (1 to $12 \%$ per species; 18), when compared to an efficient vector of PD strains (27). Citrus orchards in Brazil harbor over 20 sharpshooter leafhoppers and spittlebug species that are xylem-sap feeders (24) and thus likely to be vectors of $X$. fastidiosa to citrus. Acquisition, inoculation efficiency, numbers, and movement of vectors are important determinants of rates of infection in the field (26). A minimum population of $\log 4 \mathrm{CFU} / \mathrm{g}$ was required for acquisition of $X$. fastidiosa from grapevines by an efficient vector, and only $40 \%$ transmission rates were achieved with bacterial populations of about $\log 6$ $\mathrm{CFU} / \mathrm{g}$ (13). The average population of viable $X$. fastidiosa in field-collected citrus leaves with CVC symptoms was $\log 5$ to $\log 6 \mathrm{CFU} / \mathrm{g}$; therefore, it seems likely that bacterial population densities restrict vector transmission efficiency in citrus, at least in part, by reducing the probability of vector acquisition.

The epidemiological information available for CVC $(7,19)$ is based on symptoms rather than pathogen detection and quantification; thus, the importance of the bacterial population on disease progress throughout seasons has yet to be determined. Because most spread of the pathogen is from tree to tree within the orchards (19), vector acquisition of $X$. fastidiosa from citrus trees appears to be an important limitation for transmission to be efficient. The epidemiological importance of noncitrus hosts of $X$. fastidiosa, such as weeds, which can support high numbers of sharpshooters has not yet been determined.

\section{ACKNOWLEDGMENTS}

We thank Centro de Citricultura Sylvio Moreira-IAC for technical assistance, and M. T. C. V. Lopes and A. Wendland for help with diagnostic tests.

\section{LITERATURE CITED}

1. Beretta, M. J. G., Barthe, G. A., Ceccardi, T. L., Lee, R. F., and Derrick, K. S. 1997. A survey of strains of Xylella fastidiosa in citrus affected by citrus variegated chlorosis and citrus blight in Brazil. Plant Dis. 81:1196-1198.

2. Chagas, C. M., Rossetti, V., and Beretta, M. J. G. 1992. Electron microscopy studies of a xylem-limited bacterium in sweet orange affected with citrus variegated chlorosis disease in Brazil. J. Phytopathol. 134:306-312.

3. Chang, C. J., Garnier, M., Zreik, L., Rossetti, V., and Bové, J. M. 1993. Culture and serological detection of the xylem-limited bacterium causing citrus variegated chlorosis and its identification as a strain of Xylella fastidiosa. Curr. Microbiol. 27:137-142.

4. Davis, M. J., French, W. J., and Schaad, N. W. 1981. Axenic culture of the bacteria associated with phony disease of peach and plum leaf scald. Curr. Microbiol. 6:309-314.

5. Garnier, M., Chang, C. J., Zreik, L., Rossetti, V., and Bové, J. M. 1993. Citrus variegated chlorosis: serological detection of Xylella fastidiosa, the bacterium associated with the disease. Pages 301-305 in: Proc. 12th Conf. Int. Org. Citrus Virol. New Delhi.

6. Goodwin, P. H., DeVay, J. E., and Meredith, C. P. 1988. Roles of water stress and phytotoxins in the development of Pierce's disease of the grapevine. Physiol. Mol. Plant Pathol. 32:1-15.

7. Gottwald, T. R., Gidtti, F. B., Santos, J. M., and Carvalho, A. C. 1993. Preliminary spatial and temporal analysis of citrus variegated chlorosis (cve) in São Paulo, Brazil. Pages 327-335 in: Proc. 12th Conf. Int. Org. Citrus Virol. New Delhi.

8. Gravena, S., DeNegri, J. D., Quaggio, J. A., Gonzales, M. A., Pinto, W. B. S., and Basile, G. B. 1998. Sharpshooters and CVC management in citrus orchard. Pages 91-113 in: Citrus Variegated Chlorosis. L. C. Donadio and C. S. Moreira, eds. Fundecitrus/Fapesp, Bebedouro, SP, Brazil

9. Hartung, J. S., Beretta, J., Brlansky, R. H., Spisso, J., and Lee, R. F. 1994. Citrus variegated chlorosis bacterium: axenic culture, pathogenicity, and serological relationships with other strains of Xylella fastidiosa. Phytopathology 84:591-597.

10. He, C. X., Li, W. B., Ayres, A. J., Hartung, J. S., Miranda, V. S., and Teixeira, D. C. 2000. Distribution of Xylella fastidiosa in citrus rootstocks and transmission of citrus variegated chlorosis between sweet orange plants through natural root grafts. Plant Dis. 84:622626.

11. Hill, B. L., and Purcell, A. H. 1995. Acquisition and retention of Xylella fastidiosa by an efficient vector, Graphocephala atropunctata. Phytopathology 85:209-212.

12. Hill, B. L., and Purcell, A. H. 1995. Multiplication and movement of Xylella fastidiosa within grapevine and four other plants. Phytopathology 85:1368-1372.

13. Hill, B. L., and Purcell, A. H. 1997. Populations of Xylella fastidiosa in plants required for transmission by an efficient vector. Phytopathology 87:1197-1201

14. Hopkins, D. L. 1985. Physiological and pathological characteristics of virulent and avirulent strains of the bacterium that causes Pierce's disease of grapevine. Phytopathology 75:713-717.

15. Hopkins, D. L. 1989. Xylella fastidiosa: a xylem-limited bacterial pathogen of plants. Annu. Rev. Phytopathol. 27:271-290.
16. Hopkins, D. L., and Mollenhauer, H. H. 1973. Rickettsia-like bacterium associated with Pierce's disease of grapes. Science 179:298-300.

17. Hopkins, D. L., and Thompson, C. M. 1984 Seasonal concentration of the Pierce's disease bacterium in 'Carlos' and 'Welder' muscadine grapes compared with 'Schuyler' bunch grape. HortScience 19:419-420.

18. Krügner, R., Lopes, M. T. V. C., Santos, J. S., Beretta, M. J. G., and Lopes, J. R. S. 1998. Transmission efficiency of Xylella fastidiosa by sharpshooters and identification of two new vector species. Page 81 in: Proc. 14th Conf. Int. Org. Citrus Virol. Brazil.

19. Laranjeira, F. F., Bergamin Filho, A., and Amorim, L. 1998. Dinâmica e estrutura de focos da clorose variegada dos citros (CVC). Fitopatol. Bras. 23:36-41.

20. Lee, R. F., Beretta, M. J. G., Hartung, J. H., Hooker, M. E., and Derrick, K. S. 1993. Citrus variegated chlorosis: Confirmation of a Xylella fastidiosa as the causal agent. Summa Phytopathol. 19:123-125.

21. Minsavage, G. V., Thompson, C. M., Hopkins, D. L., Leite, R. M. V. B. C., and Stall, R. E. 1994. Development of a polymerase chain reaction protocol for detection of Xylella fastidiosa in plant tissue. Phytopathology 84:456-461.

22. Mircetich, S. M., Lowe, S. K., Moller, W. J., and Nyland, G. 1976. Etiology of almond leaf scorch disease and transmission of the causal agent. Phytopathology 66:17-24.

23. Mizubuti, E. S. G., Matsuoka, K., and Parizzi, P. 1994. Associação de bactéria do tipo Xylella em laranjeiras com sintomas de clorose variegada na região da Zona da Mata de Minas Gerais. Fitopatol. Bras. 19:241-244.

24. Paiva, P. E. B., Silva, J. L., Gravena, S., and Yamamoto, P. T. 1996. Cigarrinhas de xilema em pomares de laranja do Estado de São Paulo. Laranja 17:41-54.

25. Pooler, M. R., and Hartung, J. S. 1995. Specific PCR detection and identification of $X y$ lella fastidiosa causing citrus variegated chlorosis. Curr. Microbiol. 31:377-381.

26. Purcell, A. H. 1981. Vector preference and inoculation efficiency as components of resistance to Pierce's disease in European grape cultivars. Phytopathology 71:429-435.

27. Purcell, A. H., and Finlay, A. H. 1979. Evidence for noncirculative transmission of Pierce's disease bacterium by sharpshooter leafhoppers. Phytopathology 69:393-395.

28. Purcell, A. H., and Saunders, S. R. 1999. Fate of Pierce's disease strains of Xylella fastidiosa in common riparian plants in California. Plant Dis. 83:825-830.

29. Roberto, S. R., Coutinho, A., Lima, J. E. O., Miranda, V. S., and Carlos, E. F. 1996. Transmissão de Xylella fastidiosa pelas cigarrinhas Dilobopterus costalimai, Acrogonia terminalis e Oncometopia facialis em citros. Fitopatol. Bras. 21:517-518.

30. Rodas, V. Z. 1994. Convivência com a clorose variegada dos citros. Laranja 15:129-133.

31. Rossetti, V., Garnier, M., Bové, J. M., Beretta, M. J. G., Teixeira, A. R. R., Quaggio, J. A., and de Negri, J. D. 1990. Présence de bactéries dans le xylème d'orangers atteints de chlorose variégé, une nouvelle maladie des agrumes au Bresil. C. R. Acad. Sci. Ser. III Sci. Vie 30:345-349.

32. Wells, J. M., Raju, B. C., Nyland, G., and Lowe, S. K. 1981. Medium for isolation and growth of bacteria associated with plum leaf scald and phony peach diseases. Appl. Environ. Microbiol. 42:357-363. 